\title{
Factor Analysis Of Education Level Effect On Poverty Fisheries In Aceh Province
}

\author{
Wahyuddin ${ }^{1}$, Muksal $^{1}$, Nirzalin $^{2}$ and Zulfikar ${ }^{3}$ \\ \{muksal@serambimekkah.ac.id\} \\ ${ }^{12}$ Department of Islamic Banking and Finance, Syariah Faculty, Universitas Serambi Mekkah \\ ${ }^{2}$ Department of Sociology, FISIP, Universitas Malikussaleh \\ ${ }^{3}$ Department of Aquaculture, Agriculture Faculty, Universitas Malikussaleh
}

\begin{abstract}
Aceh has great potential in marine and fishery sectors, this a great opportunity to become a dominant sector and mainstay that can lift and increase income and welfare of fishermen community. One indicator of the cause of poverty is the uneven level of education because higher education results in better work productivity so that the impact will provide greater income. This research is intended to determine whether the level of education will effect against poverty fishermen. This type of research is quantitative research using simple linear regression testing. The sample in this research is fishermen education data and poverty of Aceh province fishermen in 2005-2016. Source of data obtained in this research is in the form of secondary data. Secondary data that writer using is taken from the Central Bureau of Statistics (BPS) period 2005-2016. Based on the results of the research can be taken conclusion that is obtained from the results of linear regression analysis using SPSS showed that the education variables obtained results from the t-test of -5.251 with $p$-value of 0.001 , This indicates that there is a negative influence and significant of Education (XI) on Poverty (Y1) fishermen in Aceh province.
\end{abstract}

Keywords: Poverty, Fisherman, Illegal Fishing, Fisherman's Economy, Welfare.

\section{Introduction}

Aceh is a province that has the highest poverty rate in Indonesia, reaching 26,65 percent in 2007 and became 19,57 in 2011 The average economic growth in Aceh is minus 1.09 percent. The highest decrease in economic growth occurred in 2009 which reached minus 5,51 percent. This poverty is very regrettable because Aceh has a various potential for economic growth, one of which is the maritime area. ${ }^{[15]}$ According to Aceh's land area of 57,365,65 square kilometers, surrounded by the Indian Ocean in the south-western region of Aceh, and the Malacca Strait and the waters in the north-eastern region of Aceh, with a coastline length of 2,666.27 kilometers. While the water area reaches 295,370 square kilometers consisting of territorial waters and the island of 56,563 square kilometers, as well as the waters of Exclusive Economic Zone (ZEE) 238,807 square kilometers. The sustainable potential is estimated to reach 272,7 thousand tons/year, the number of fishing vessels 16,701 units the number of fishermen 64,466 people. This condition is very strategic for fisheries business, especially 
fishing in the sea and aquaculture ponds. Thus making the province of Aceh as one of the areas that have great potential and a great opportunity in the marine and fishery is to be a dominant and reliable sector that can lift and improve the income and welfare of the people of Aceh. The poverty is one of the troubles in the economy so that it must be cured or at least reduced. The problem of poverty is a complex and multidimensional problem both nationally and internationally, not least in Aceh Province. One of the indicators that cause of poverty is the uneven level of education because higher education leads to better work productivity so that the impact will provide greater income. ${ }^{[16]}$ The poor generally cannot read because they cannot afford to go to school, do not have jobs, afraid of the future, the loss of children because of the pain and the uncertainty of life in the future that they feel.

If education in a nation is not good, then the nation's development will not develop properly, such as the increase of unemployment rate that is very influential to the level of poverty of a region, ${ }^{[7]}$ assuming logic; the difficulty of a person getting an education will cause a person difficulty in finding a job. Along with the development of the available employment period, only receive employment that has a high level of education. If in the education period many people who do not take the education properly then the community will have difficulty to find a job. The difficulty of finding this job will result in someone having difficulty earning income. So they are not able to meet their life needs, ${ }^{[9]}$ in other words; Community income reaches maximum if full employment rate conditions can be realized. So education is one way to get people out of the poverty trap.

From the above description then, the author would like to test a hypothesis:

H1: The Education Level of Fishermen Influence Negative and Significant To Fisherman Poverty Rate in Aceh Province.

\section{Methodology}

In the sustainable economic development, education is considered as a very important role to achieve a sustainable, ${ }^{[14]}$ because with education development activities can be achieved, so the opportunity to improve the quality of life in the future will be better. Value of Education can increase the ability of the population to obtain and use information, deepen understanding of the economy, expand productivity, and give choice to the population whether to act as a consumer, producer or citizen. In addition, education and income distribution have a positive correlation with their income during one's life. ${ }^{[12]}$ Hermanus explains Poverty based on the cause is divided into two kinds. First is the cultural poverty that is poverty caused by the custom or culture of a particular region so as to keep it inherent with poverty, second, structural poverty where the poverty is happening caused by the powerlessness of the community or certain group against the system or the social order. Therefore, efforts to alleviate poverty should be done comprehensively, covering various aspects of community life, and implemented in an integrated manner. The term poverty arises when a person or group of people does not sufficiently meet the level of economic prosperity that is considered a minimal need of a certain standard of living. ${ }^{[12]}$

The resulting study of Kuncoro in $[1]^{[11]}$ gives a choice of profession with the amount of income earned by a person who works as a farmer has $4.82 \%$ income, people who work as employees both service and production and sales have an income of 7-9\% while working as manager and employers earn an income of 35\%. From the results of this study, it can be concluded that work with higher levels of education will provide a greater income. The results 
of the study were conducted by [2], ${ }^{[2]}[3],{ }^{[1]}$ Ukwuezze $(2014),{ }^{[13]}$ Zechariah $(2006){ }^{[17]}$ and [4] ${ }^{[5]}$ concluded that educational levels had an influence on the number of poor people. This is in line with the opinion of $[5],{ }^{[6]}$ who stated that the influence of education level on poverty shows a positive but insignificant relation pattern to poverty with regression coefficient value of 5,333, meaning that the increase of education level will increase the poverty rate of 5,333. This is because education has not been followed by skill level so that it is not productive. Low level of education causes job choice to fulfill the necessity of life to be limited so that the choices are usually taken only rely on the power so that the income becomes low. The local communities that had little education are synonymous with poverty. Therefore, it is important for the public, especially the government to improve the living standards of the community to reduce poverty by improving the quality of education. [6] ${ }^{[3]}$ states that there is a relationship which is very close between the high level of unemployment and poverty, because the income level is greatly influenced by the length of the year to get an education, obviously the huge income inequality will be greater.[8]

Poverty alleviation is an increase in productivity, increased incomes, and improvement of living standards, so as to prevent from negative activities. ${ }^{[10]}$ If poverty alleviation is not carried out perfectly it will lead to chronic poverty. Chronic Poverty is caused by several things, namely: a) Socio-cultural conditions that encourage attitudes and habits of people who are not productive; ${ }^{[4]}$ b) Limited resources and isolation (critical areas of natural resources and remote areas); c) The low level of education and the degree of health care, the limited employment and the powerlessness of the community in following the market economy.

\subsection{Types Of Research}

This research uses quantitative approach and uses statistical calculation technique. In this case, the quantitative approach is done by analyzing the Fishermen education data and its impact on the poverty of fishermen in Aceh province.

\subsection{Population and Sample}

Based on research data, the population in this research is fisherman education data and poverty of fisherman in Aceh province. The sample in this research is education data of fisherman and poverty of fisherman of the province of Aceh year 2005-2016. Source of data obtained in this research is in the form of secondary data. Secondary data that the authors use is based on data Central Bureau of Statistics (BPS) period 2005-2016.

\subsection{Data Analysis Technique}

\subsubsection{Statistical Analysis}

The results of data processing are used to answer the problems that have been formulated. This analysis is used to show the relationship between the independent variable $(\mathrm{X})$ with the dependent variable (Y). Statistical analysis includes:

\subsubsection{Classic Assumption Test}

In this study, researchers will perform statistical tests regression in studying the relationship that exists between the dependent variables if the independent variables are known or vice versa. In practice, there are four most commonly used classical assumptions namely:

1.1 Normality test, This test is done to see if the distribution of data available is normally distributed or not. One of the statistical tests that can be used to test residual normality is 
non-parametric statistical test Kolmogorov-Smirnov (KS). The KS test is done by making a hypothesis:

Ho : The residual data is normally distributed

Ha : Residual data is not normally distributed

Decision-making guidelines:

a. Sig value or significance or probability value $<0.05$. Distribution is not normal.

b. Sig value or significance or probability value $>0.05$. Distribution is normal.

1.1. Multicollinearity test

Multicollinearity test aims to test whether the regression model found the correlation between independent variables. If independent variables are correlated, these variables are not orthogonal. To detect whether there are the indications of multicollinearity or not can be seen from the tolerance and VIF (variance inflation factor). If a low tolerance value is equal to a high VIF value, then it indicates a high collinearity (because of VIF $=1$ / Tolerance). Cut off values commonly used to indicate multicollinearity are tolerance values $<0.10$ or equal to $\mathrm{VIF}>10$.

\subsection{Heteroscedasticity Test}

Heteroscedasticity test aims to test whether in the regression model there is a variance inequality of one observation residual to another observation. To test whether the variant of residual homogeneous used Spearman rank test, that is by correlating the five independent variables to the absolute value of the residual (error). If there is a significant independent variable correlation coefficient at the error rate of $5 \%$, indicating the occurrence of Heteroscedasticity.

\subsection{Autocorrelation Test}

Autocorrelation test aims to test whether in the linear regression model there is a correlation between the confounding errors in period $t$ with the intruder error in period $t-1$ (previous). The way used to diagnose autocorrelation is by the Durbin-Watson test (DW test). Decision-making whether there is autocorrelation or not (Imam Ghozali, 2007) is:

a. If DW is located between the upper bound /du and 4-du, then there is no autocorrelation.

b. If DW is lower than Lower bound / $\mathrm{dl}$ ) then there is a positive autocorrelation.

c. If the DW value is greater than (4-dl), then there is a negative autocorrelation.

d. If the DW value lies between (4-du) and between (dl-du) then the result cannot be concluded.

\subsubsection{Simple Linear Regression Test}

Regression can be used to predict how far the value of the dependent variable changes if the value of the independent variable is changed. In addition, Regression analysisis used to measure the strength of the relationship between two variables; it also indicates the direction of the relationship between the dependent variable and independent variables.

Explanation:

$$
\mathbf{Y}=\boldsymbol{\alpha}+\boldsymbol{\beta} \mathbf{X}+\boldsymbol{\varepsilon}
$$

$\mathrm{Y}=$ Poverty

$\alpha=$ Constant, i.e. the value of $Y$ when $X=0$

$\beta=$ The direction of regression coefficient, which states the change of $Y$ value if there is a change of $X$ value. If $(+)$ then the direction of the line will rise, and if $(-)$ then the line value will drop

$\mathrm{X}=$ Education

$\varepsilon=$ other factors affecting variable $\mathrm{Y}$ 


\subsubsection{Hypothesis Testing}

The statistical t-test basically shows how far the influence of a partially independent variable in explaining the dependent variable. This test is a two-way test with the hypothesis:

$\mathrm{H} 0: \beta 1=0$ means that there is no influence from the independent variable to the dependent variable.

Ha: $\beta 1<0$ or $\beta 1>0$ means that there is influence from independent variable to dependent variable.

To calculate the value of tused the formula:

$$
t_{\text {count }}=\beta 1: \operatorname{Se}(\beta 1)
$$

Where:

$\beta 1=$ correlation coefficient

$\mathrm{Se}(\beta 1)=$ standard error regression coefficient

Testing criteria:

a. H0 is accepted and Ha is rejected if $\mathrm{t}$-count $<\mathrm{t}$-tabel, meaning that independent variable has no significant effect on dependent variable.

b. H0 rejected and $\mathrm{Ha}$ accepted if $\mathrm{t}$-count $>\mathrm{t}$-table, meaning that independent variables significantly influence the dependent variable. Another alternative to see the effect of partial is to see the significance value if the value of significance formed under $5 \%$ then there is a significant influence of independent variables partially on the dependent variable. Conversely, if the significance is formed above $5 \%$ then there is no significant effect of independent variables partially on the dependent variable.

\section{Result and Discussion}

\subsection{Classic Assumption Test Result}

Hypothesis testing with linear regression model should avoid any deviation of classical assumption. Testing the classical assumption is intended for the variable Education indication (XI) to be the estimator of the dependent variable Poverty (Y1) is not biased. If there is no indication of the classical assumption that is autocorrelation, multicollinearity, heteroscedasticity, normality, and linearity in hypothesis testing with the model used, hence expected to produce a good model so that the result of analysis also good and not bias.

\subsection{Normality Test}

The results of normality test (Kolmogorov-Smirnov test) can be seen in table 1 below:

Table 1. Normality Test Results (Kolmogorov-Smirnov Test)

\begin{tabular}{cl}
\hline Significance & Conclusion \\
\hline 0.200 & $\mathrm{H} 0$ accepted \\
\hline
\end{tabular}

Source: Data processed

The result of the normality test (Kolmogorov- Smirnov test) in table 1 above shows that the asymp value. Sig. of 0.178 , this indicates that the sig value is greater than the value of confidence $(\mathrm{a}=0.05)$. Therefore it can be concluded that $\mathrm{Ha}$ rejected and $\mathrm{H} 0$ is received so that the residual data is normally distributed. 


\subsection{Multicollinearity Test}

Multicollinearity test results (VIF test) can be seen in table 2 below:

Table 2. Multicollinearity Test Results (VIF Test)

\begin{tabular}{ccc}
\hline Independent variable & Tolerance & VIF \\
\hline Poverty & 1.000 & 1.000 \\
\hline \multicolumn{3}{c}{ Source: Data processed }
\end{tabular}

Based on the output Table 2 above it is known that: The Toerance Value of Education variables (X1) i.e. 1,000 is greater than 0.10. Meanwhile, the VIF Value of Education variable (X1) is 1,000 smaller than 10.00 . So it can be concluded that Multicolinearity does not occur.

\subsection{Heteroscedasticity Test}

The results of heteroscedasticity test (Glejser test) can be seen in table 3 below:

Table 3. Heteroscedasticity Test Results (Park Test)

\begin{tabular}{ccc}
\hline Variables & Significance & Conclusion \\
\hline Poverty & 0.563 & Non Heteroscedasticity \\
\hline & Source: Data processed
\end{tabular}

Based on the output in Table 3 above, it is known that the significance value of Education (X1) variables of 0,905 is greater than 0.05 , meaning that there is no heteroscedasticity.

\subsection{Autocorrelation Test}

The autocorrelation test results can be seen in table 4 below:

Table 4. Autocorrelation Test Results ( Run Test)

\begin{tabular}{ccc}
\hline Variables & Durbin-Watson & Conclusion \\
\hline Poverty & 2.320 & H0 accepted \\
\hline \multicolumn{3}{c}{ Source: Data Processed }
\end{tabular}

Based on the above output, the value of DW 2,320, then we will compare this value with $5 \%$ significance table value, the number of samples $\mathrm{N}=10$ and the number of independent variables $1(\mathrm{~K}=1)=1.10$ then obtained the value of du 1,319. Value DW 2,320 greater than the upper limit (du) that is 1.319 and less than (4-du) $4-1,319=2,681$ so it can be concluded that there is no autocorrelation.

\subsection{Simple Linear Regression Test Result}

The results of Simple Linear Regression test can be seen in table 5 below:

Table 5 Regression Test Results

\begin{tabular}{llll}
\hline Variables & T & Significance & Results \\
\hline Education & -5.251 & 0.001 & H1 Accepted \\
\hline \multicolumn{4}{c}{ Source: Data processed }
\end{tabular}


Based on the results of Simple Linear Regression test the influence of Education (XI) on Poverty (Y1) using SPSS program obtained t-count -5.251 with $\mathrm{p}$-value 0.001 . This indicates that there is a negative and significant effect of Education (XI) on Poverty (Y1).

The result of linear regression analysis using SPSS showed that from Educational variables obtained the result from t-test result equal to $-5,251$ with value $\mathrm{p}$-value 0.001 , It shows that there is the influence of Negative and significant Education (XI) to Poverty (Y1). These results indicate that when fishermen have a high education will reduce poverty in a region. This suggests that one of the causes of poverty is the uneven level of education because higher education results in better work productivity so that the impact will provide greater income. ${ }^{[16]}$ Poor fishermen who do not have a high level of education generally cannot read and do not have skilled job skills, fear of the future, the loss of children due to illness and the uncertainty of life in the future that they feel. Fishermen with low education have only one job and it is very difficult to get another job, the difficulty of finding this job will result in the fisherman having trouble earning income. So they are not able to meet their life needs, ${ }^{[9[}$ in other words; Fishermen's income reaches the maximum when full employment rate conditions can be realized. It is also supported by Kuncoro's research results in $[1]^{[9]}$ From the results of these studies it can be concluded that jobs with higher levels of education will provide greater income.

\section{Conclusion}

Based on the results of the research can be taken conclusion that is obtained from the results of linear regression analysis using SPSS showed that the education variables obtained results from the test t-test of -5.251 with p-value 0.001 , This indicates that there is a negative and significant influence Education (XI) on Poverty (Y1). Low-educated fishermen have only one job and it is very difficult to get another job, the difficulty of finding this job will result in the fisherman having trouble earning income. The higher level of education owned by the fisherman then the competence of the fisherman will be higher. This will affect the income level of the fishermen. With a high level of income then the fishermen can avoid poverty. So the more people who have a higher education level will be the less number of poor people in Aceh.

\section{Acknowledgements}

The researcher would like to thank the Ministry of Research, Technology and Higher Education of the Republic of Indonesia, as this research is part of the core research that the writer did, Institute for Research and Community Service (LP2M) University of Serambi Mekkah Aceh which has become a forum for researchers, to the partner research team from the University of Malikussaleh Aceh: Dr. Nirzalin, M.Si and Dr. Zulfikar S.Pi., M.Si who became partner in this research, and to all the fisherman's sources, Panglima Laot and the related offices that support the success of this research. 


\section{References}

[1] Subli, "Hubungan kemiskinan dan factor-faktor penyebabnya pada masyarakat desa kembang Janggut dan Kota Bangun II Kutai Kartanegara," Tesis, Pascasarjana Universitas Mulawarman, Samarinda, 2005.

[2] S. Appleton, "Education, incomes and poverty in Uganda in the 1990s," Credit Res. Pap., no. 01, p. 34 p., 2001.

[3] N. K. Aksentijevi, N. D. Bogovi, and Z. Je, "Education , poverty and income inequality in the," vol. 24, pp. 19-38, 2006.

[4] T. Capra, "Poverty and its impact on education," pp. 75-81, 2009.

[5] A. Fahmi, "Faktor Pendidikan dan Kesehatan Berpengaruh Terhadap Kemiskinan di Provinsi Jambi," J. Dev., pp. 89-103, 2014.

[6] L. Arsyad, Ekonomi Pembangunan. Yogyakarta: STIE YKPN, 1997.

[7] Barika. (2013).Pengaruh Pertumbuhan Ekonomi, Pengeluaran Pemerintah,Pengangguran Dan Inflasi Terhadap Tingkat Kemiskinan DiProvinsi Se-Sumatera, Jurnal Ekonomi Dan Perencanaan Pembangunan, Volume : 05. No. 01.

[8] Fatma, F. S.(2005).Pengaruh Inflasi dan Pengangguranterhadap Kemiskinan di Indonesia" Tesis, Magister Sains Ekonomi Program Pascasarjana fakultas Ekonomi Universitas Indonesia.

[9] Gaiha, R. (1993). Design Of Poferty Allevation Strategy In Rural Areas. Fao. Roma

[10] Maulidah, F.,(2015) Pengaruh Tingkat Pendidikan, Pendapatan dan Konsumsi Terhadap Jumlah Penduduk Miskin di Provinsi Jawa Timur, Jurnal Ekonomi Pendidikan dan Kewirausahaan, Vol. 3. No. 1.

[11] Robino, D. J. (2006). The Self-Esteem Book The Ultimate Guide To Boost The Most Underrated IngredientFor Success And Happiness In Life. Vision Works Publishing.

[12] Susanto, E., Rochaida, E., Ulfah, Yana.,(2017). Pengaruh Inflasi Dan Pendidikan Terhadap Pengangguran Dan Kemiskinan, Journal Inovasi Unmul Volume 13 (1), , 19-27.

[13] Ukwueze, E., Emmanuel, N. (2014). Does Higher Education Reduce Poverty Among Youth in Nigeria.Asian Economic and Financial Review, Vol. 4, No. 1, (PP: 1-19).

[14] Wahyuddin, Muksal, Nirzalin \& Zulfikar. (2017) "Pengaruh Praktik Illegal Fishing Terhadap Kesejahteraan Ekonomi Nelayan Di Provinsi Aceh" Prosiding Seminar Nasional II USM 2017, Eksplorasi Kekayaan Maritim Aceh di Era Globalisasi dalam Mewujudkan Indonesia sebagai Poros Maritim Dunia, Vol. 1, Oktober 2017, 411-417.

[15] Wahyuddin, Muksal, Nirzalin \& Zulfikar.(2018) "The Role Of Government In Increasing Fisherman's Economic Welfare In Aceh Province" American Scientific Publishers, Advanced Science Letters, Vol. 24, 518-520.

[16] Wehelmina, (2004) Pengaruh Tingkat Pendidikan Terhadap Kemiskinan Di Kabupaten Sitaro, Jurnal Logos Spectrum, ISSN 1907-316x, vol 9, No 1 Januari-Maret 2014, Hal 28-33.

[17] Zakharia, Z. (2006). Education and Poverty in an International Context. Society for International Education Teacher College Columbia University, (PP: 15- 35). 